\title{
IMPLEMENTASI MODEL PEMBELAJARAN CHILDREN LEARNING IN SCIENCE (CLIS) UNTUK MENINGKATKAN HASIL BELAJAR IPS PESERTA DIDIK KELAS VIII DI SMP NEGERI 1 BUAY PEMUKA PELIUNG
}

\author{
Oktavia Pawari ${ }^{1}$, Vovi Sinta ${ }^{2}$, Miftakhur Rohmah ${ }^{3}$ \\ ${ }^{1,2,3}$ Prodi Pendidikan Ekonomi STKIP Nurul Huda OKU Timur \\ *E-mail: vovisinta@gmail.com
}

\begin{abstract}
Abstrak:Model pembelajaran IPS di SMP Negeri 1 Buay Pemuka Peliung bersifat terpusat yang mengakibatkan hasil belajar peserta didik rendah Tujuan penelitian ini adalah untuk mengetahui peningkatan hasil belajar mata pelajaran IPS peserta didik melalui implementasi model pembelajaran Children Learning In Science (CLIS). Penelitian ini penelitian tindakan kelas model Kurt Lewin yang dilakukan dalam 3 siklus. Subjek penelitian peserta didik kelas VIII-2 berjumlah 34 orang. Teknik pengumpulan data observasi dan tes. Analisis data deskriptif kuantitatif menghitung ketuntasan belajar peserta didik tiap siklus. Hasil penelitian menunjukkan bahwa hasil belajar mata pelajaran IPS sebelum tindakan hanya mencapai $17,65 \%$ (rendah) dengan nilai rata-rata 40,00. Hasil belajar mata pelajaran IPS peserta didik setelah tindakan mencapai $94,12 \%$ dengan nilai rata-rata 80,00 . Implementasi model pembelajaran Children Learning In Science (CLIS) dapat meningkatkan hasil belajar IPS peserta didik kelas VIII SMP Negeri 1 Buay Pemuka Peliung setiap siklusnya sebesar $25,49 \%$.
\end{abstract}

Kata Kunci: Children Learning In Science (CLIS), Hasil Belajar.

\section{PENDAHULUAN}

Pendidikan merupakan sebuah proses dengan metode-metode tertentu sehingga seseorang memperoleh pengetahuan, pemahaman dan cara bertingkah laku sesuai kebutuhan. Undang-undang Republik Indonesia Nomor 20 Tahun 2003 tentang Sistem Pendidikan Nasional pasal 1 ayat 1 yang menyatakan bahwa:

"Pendidikan adalah usaha sadar dan terencana untuk mewujudkan suasana belajar dan proses pembelajaran agar peserta didik secara aktif mengembangkan potensi dirinya untuk memiliki kekuatan spiritual keagamaan, pengendalian diri, kepribadian, kecerdasan, akhlak mulia, serta keterampilan yang diperlukan dirinya, masyarakat, bangsa dan negara" (Depdiknas, 2010:2).

Penjelasan sebagaimana tersebut menunjukkan bahwa pendidikan ditekankan pada proses pembinaan kepribadian peserta didik secara menyeluruh sehingga peserta didik menjadi lebih dewasa melalui kegiatan belajar. Berkaitan pengertian 
belajar, Suyono (2011:9) mengemukakan, "belajar adalah suatu aktivitas atau suatu proses untuk memperoleh pengetahuan, meningkatkan keterampilan, memperbaiki perilaku, sikap, dan mengokohkan kepribadian sebagai bentuk dari hasil belajar".

Berkaitan pengertian hasil belajar, Suprijono (dalam Mustofa, 2011:22), mengemukakan bahwa, "hasil belajar adalah pola-pola perbuatan, nilai-nilai, pengertian-pengertian, sikap-sikap, dan keterampilan yang diperoleh seseorang melalui kegiatan belajar". Ketercapaian hasil belajar banyak dipengaruhi oleh berbagai faktor. Salah satu faktor yang mempengaruhi proses serta ketercapaian hasil belajar adalah pendekatan pembelajaran yang diterapkan pendidik.

Sukardi (2013:22) mengemukakan, "yang dimaksud dengan faktor pendekatan adalah jenis upaya belajar peserta didik yang meliputi strategi dan model yang digunakan untuk melakukan kegiatan pembelajaran materi-materi pembelajaran". Penjelasan tersebut menunjukkan bahwa model pembelajaran sebagai alat pencapaian tujuan memerlukan pengetahuan tentang tujuan itu sendiri. Hariyati dalam jurnal ilmiahnya (2015:2) bahwa "model pembelajaran harus dipilih sesuai dengan karakteristik peserta didik, ketersediaan sarana pembelajaran, dan materi pembelajaran". Kekurang tepatan model pembelajaran yang diterapkan pada pembelajaran akan berimplikasi pada efektifitas pembelajaran yang dilaksanakan dan pencapaian hasil belajar peserta didik.

Berdasarkan hasil surve awal yang dilakukan oleh peneliti pada tanggal 10 September sampai 10 November 2018 menunjukkan bahwa terdapat kelemahan sistem pembelajaran IPS di kelas VIII SMP Negeri 1 Buay Pemuka Peliung baik dari faktor pendidik maupun dari faktor peserta didik. Dari faktor pendidik kelemahan yang terjadi dalam pembelajaran IPS di SMP Negeri 1 Buay Pemuka Peliung adalah pelaksanaan pembelajaran oleh pendidik dilakukan menggunakan model pembelajaran yang berpusat pada pendidik yaitu model pembelajaran klasikal tanpa variasi dengan model pembelajaran lain. Pembelajaran demikian menjadikan pendidik sebagai sentral pembelajaran yang aktif, sedangkan peserta didik hanya menjadi pendengar pasif sehingga pemahaman terhadap materi pembelajaran serta pencapaian hasil belajar peserta didik pun menjadi rendah sebagaimana hasil dokumentasi nilai harian peserta didik kelas VIII-2 yang menunjukkan dari 34 peserta didik hanya terdapat 13 atau 38,24\% yang mencapai kriteria ketuntasan minimal 70 .

Kelemahan pembelajaran IPS di kelas VIII SMP Negeri 1 Buay Pemuka Peliung juga terjadi pada faktor peserta didik. Hasil survei awal menunjukkan bahwa selama kegiatan pembelajaran peserta didik bersikap pasif. Ketika pendidik memberikan kesempatan kepada peserta didik untuk mengajukan pertanyaan, hanya beberapa orang peserta didik yang dapat mengajukan pertanyaan. Ketika pendidik menjelaskan materi pembelajaran sebagian kecil peserta didik yang memperhatikan penjelasan pendidik, sedangkan peserta didik lain terlihat bersikap apatis.

Permasalahan yang kerap terjadi pada pembelajaran IPS di kelas VIII SMP Negeri 1 Buay Pemuka Peliung, peneliti menawarkan model pembelajaran baru untuk diterapkan yaitu Children Learning In Science (CLIS). Berkaitan dengan model 


\section{IMPLEMENTASI MODEL PEMBELAJARAN CHILDREN LEARNING IN SCIENCE (CLIS) UNTUK MENINGKATKAN HASIL BELAJAR IPS PESERTA DIDIK KELAS VIII DI SMP NEGERI 1 BUAY PEMUKA PELIUNG}

pembelajaran Children Learning In Science (CLIS) IImi dalam jurnal ilmiahnya (2012:8) menyatakan, "model pembelajaran CLIS ialah model pembelajaran yang mengungkapkan pertukaran gagasan antara peserta didik dengan tenaga pendidik dalam rangka pembukaan situasi, kontruksi gagasan baru serta evaluasi."

Penggunaan model pembelajaran Children Learning In Science (CLIS) pada penelitian ini karena model pembelajaran Children Learning In Science (CLIS) merupakan suatu model pembelajaran yang melibatkan peserta didik dalam kegiatan eksperimen, menyajikan, menginterpretasi, memprediksi dan menyimpulkan materi pembelajaran sesuai keadaan riil di lingkungan sekitar. Selain alasan sebagaimana tersebut, pemilihan model pembelajaran Children Learning In Science (CLIS) didasarkan pada teori bahwa model pembelajaran Children Learning In Science (CLIS) memiliki beberapa kelebihan dalam pelaksanaannya seperti dapat membiasakan peserta didik dalam memecahkan suatu masalah, dapat menciptakan kreativitas peserta didik sehingga dalam pelaksanaan pembelajaran dapat lebih menarik dan tidak membosankan.

Penjelasan model pembelajaran Children Learning In Science (CLIS) menjadikan peneliti tertarik untuk melakukan penelitian berbentuk eksperimen sehingga model pembelajaran Children Learning In Science (CLIS) dipilih sebagai model pembelajaran untuk diterapkan pada pembelajaran IPS di kelas VIII SMP Negeri 1 Buay Pemuka Peliung. Alasan pemilihan lokasi penelitian adalah peneliti telah memiliki pengetahuan tentang karakteristik peserta didik, mengetahui karakteristik pendidik mata pelajaran IPS, dan peneliti telah mengetahui kelengkapan belajar yang ada di SMP Negeri 1 Buay Pemuka Peliung. Oleh karena itu, dirumuskan judul "Implementasi Model Pembelajaran Children Learning In Science (CLIS) Untuk Meningkatkan Hasil Belajar IPS Peserta Didik Kelas VIII SMP Negeri 1 Buay Pemuka Peliung".

\section{METODE}

Berdasarkan jenis data serta teknik analisis data yang digunakan, penelitian ini termasuk penelitian tindakan kelas. Penelitian tindakan kelas dilakukan secara sistematis dalam siklus-siklus berkelanjutan menggunakan desain Kemmis dan Mc Taggart. Wiriatmaja (2015:27) menjelaskan bahwa "Desain penelitian tindakan kelas yang dikemukakan oleh Kemmis dan Mc Taggart adalah merupakan model pengembangan dari model Kurt Lewin". Desain penelitian terdiri atas siklus-siklus berkelanjutan. Setiap siklus terdiri atas empat tahapan yaitu perencanaan, pelaksanaan, observasi, kemudian diakhiri dengan refleksi. Satu siklus merupakan tindakan perbaikan dari siklus sebelumnya dan kegiatan siklus dinyatakan selesai apabila target penelitian telah tercapai.

Objek penelitian ini adalah proses pembelajaran IPS melalui penerapan model pembelajaran Children Learning In Science (CLIS) di kelas VIII SMP Negeri 1 Buay 
Pemuka Peliung. Subjek dari penelitian ini adalah peserta didik kelas VIII-2 yang berjumlah 34 peserta didik dengan perincian 17 peserta didik laki-laki dan 17 peserta didik perempuan. Data-data pada penelitian ini dikumpulkan menggunakan dua teknik yaitu observasi dan tes. Asrori (2011:51) mengatakan, "Analisis data dalam penelitian tindakan kelas dilakukan melalui refleksi pada setiap tahapan siklus tindakan". Melalui kegiatan refleksi pendidik sebagai peneliti akan memiliki wawasan bersifat mendalam dan otentik sangat membantu dalam menafsirkan atau memberikan makna hasil penelitian tindakan. Analisis data dilakukan terhadap berbagai data yang telah dikumpulkan berdasarkan instrumen pengumpulan data yang telah disusun. Analisis dilaksanakan dengan menghitung ketuntasan belajar peserta didik setiap siklus.

\section{HASIL DAN PEMBAHASAN}

\section{Hasil}

Pelaksanaan kegiatan penelitian didasarkan pada hasil observasi pendahuluan mulai tanggal 10 September sampai 10 November 2018 yang menunjukkan bahwa dalam pelaksanaan pembelajaran IPS di SMP Negeri 1 Buay Pemuka Peliung, pendidik sering menggunakan model pembelajaran tradisional yang berpusat pada pendidik. Pelaksanaan pembelajaran IPS di SMP Negeri 1 Buay Pemuka Peliung yaitu materi pembelajaran disampaikan secara lisan. Pendidik menjelaskan materi pembelajaran secara lisan, memberikan contoh soal, kemudian menugaskan peserta didik mengerjakan soal. Pembelajaran sebagaimana tersebut mengakibatkan aktivitas serta keterlibatan peserta didik pada proses pembelajaran menjadi rendah sehingga pemahaman peserta didik terhadap materi pembelajaran juga rendah. Hal tersebut sebagaimana ditunjukkan hasil hasil dokumentasi nilai harian peserta didik kelas VIII-2 yang menunjukkan dari 34 peserta didik hanya terdapat 13 atau $38,24 \%$ yang mencapai kriteria ketuntasan minimal 70 . Data tersebut mengindikasikan ada permasalahan proses pembelajaran IPS di kelas VIII SMP Negeri 1 Buay Pemuka Peliung. Setelah dilakukan identifikasi masalah, diketahui bahwa masalah terjadi karena kurangnya aktivitas belajar peserta didik dalam mendalami materi pembelajaran dan pemahaman peserta didik terbatas pada penjelasan pendidik. Oleh karena itu, perlu dicobakan model pembelajaran yang lebih menekankan pada aktivitas belajar peserta didik sehingga peserta didik dapat lebih memahami materi pembelajaran.

Berdasarkan masalah yang ditemukan pada pembelajaran IPS di kelas VIII SMP Negeri 1 Buay Pemuka Peliung, perlu dilakukan perubahan model pembelajaran yang menekankan pada aktivitas belajar peserta didik seperti model pembelajaran Children Learning In Science (CLIS). Model pembelajaran CLIS memiliki karakter bahwa peserta didik diberi kesempatan untuk mengungkapkan berbagai gagasan tentang topik yang dibahas dalam pembelajaran, mengungkapkan 


\section{IMPLEMENTASI MODEL PEMBELAJARAN CHILDREN LEARNING IN SCIENCE (CLIS) UNTUK MENINGKATKAN HASIL BELAJAR IPS PESERTA DIDIK KELAS VIII DI SMP NEGERI 1 BUAY PEMUKA PELIUNG}

gagasan serta membandingkan gagasan dengan gagasan peserta didik lain dan mendiskusikan untuk menyamakan persepsi. Model pembelajaran CLIS memiliki beberapa kelebihan dalam pelaksanaannya seperti dapat membiasakan peserta didik dalam memecahkan suatu masalah, dapat menciptakan kreativitas peserta didik sehingga dalam pelaksanaan pembelajaran dapat lebih menarik dan tidak membosankan, dapat tercipta pembelajaran yang bermakna hal ini terjadi karena peserta didik merasa bangga terhadap dirinya yang telah berhasil mencipkatan konsep ilmiah yang sedang dipelajari, peserta didik dapat menganalisis contoh fenomena alam yang berhubungan dan yang sesuai dengan materi yang dipelajari karena pendidik sering memberikan contoh real dalam kehidupan nyata.

Penelitian dilaksanakan menggunakan desain tindakan kelas di kelas VIII-2 SMP Negeri 1 Buay Pemuka Peliung. Waktu pelaksanaan penelitian disesuaikan dengan kalender pendidikan sekolah bersangkutan. Penelitian ini dilaksanakan pada semester gazal Tahun Pelajaran 2019/2020. Penelitian tindakan kelas adalah suatu bentuk kajian bersifat reflektif dilakukan oleh pelaku tindakan untuk meningkatkan kemantapan rasional dari tindakan-tindakannya untuk melaksanakan tugas serta memperdalam pemahaman terhadap kondisi praktis pembelajaran. Penelitian tindakan kelas dilakukan secara sistematis dalam siklus-siklus berkelanjutan. Tindakan setiap siklus merupakan kelanjutan dari siklus berikutnya.

Penelitian ini merupakan penelitian tindakan kelas yang dilaksanakan di kelas melalui proses pembelajaran. Seluruh kegiatan siklus diikuti oleh 34 orang peserta didik. Data pada setiap siklus meliputi data hasil observasi aktivitas belajar peserta didik, data hasil observasi aktivitas pendidik serta data tes hasil belajar mata pelajaran IPS peserta didik. Kegiatan pembelajaran pada setiap siklus dilaksanakan oleh peneliti sebagai pendidik, kolaborator atau teman sejawat sebagai observer serta peserta didik. Penelitian ini direncanakan akan dilaksanakan melalui siklus berkelanjutan. Masing-masing siklus dilaksanakan melalui empat tahap yaitu perencanaan, pelaksanaan, observasi dan refleksi. Setiap siklus dilaksanakan satu kali pertemuan dengan alokasi waktu $2 \times 40$ menit. Apabila hasil refleksi siklus menunjukkan bahwa pembelajaran belum maksimal sehingga belum memenuhi target, maka penelitian dilanjutkan pada siklus berikutnya. Kegiatan pembelajaran melalui siklus dianggap berakhir pabila target yang ditentukan yaitu $90 \%$ peserta didik mencapai ketuntasan. Hasil dari kegiatan penelitian dapat dideskripsikan sebagai berikut:

- Hasil Belajar Peserta Didik Prasiklus

Hasil belajar mata pelajaran IPS peserta didik kelas VIII-2 SMP Negeri 1 Buay Pemuka Peliung pada tindakan prasiklus adalah rendah. Data menunjukkan terdapat 26 peserta didik atau 76,47\% memperoleh nilai kategori rendah, 8 peserta didik atau $23,53 \%$ memperoleh nilai kategori sedang, dan tidak terdapat peserta didik atau $0 \%$ memperoleh nilai kategori tinggi dan sangat rendah. Selain itu berdasarakan tingkat ketuntasan belajar peserta didik, hasil belajar mata pelajaran IPS peserta didik kelas 
VIII-2 SMP Negeri 1 Buay Pemuka Peliung menunjukkan bahwa dari 34 peserta didik hanya terdapat 6 peserta didik atau 17,65\% dapat mencapai ketuntasan. Hasil belajar mata pelajaran IPS peserta didik kelas VIII-2 SMP Negeri 1 Buay Pemuka Peliung adalah sangat rendah. Hal tersebut karena ketuntasan belajar sebesar $17,65 \%$ berada pada interval $1 \%-25 \%$ yang berarti ketuntasan belajar peserta didik adalah sangat rendah. Oleh karena itu, perlu dilaksanakan tindakan untuk memperbaiki proses serta hasil belajar peserta didik yang dalam hal ini melalui penerapan model pembelajaran CLIS melalui tindakan penelitian kelas

- Hasil Belajar Peserta Didik Setiap Siklus

Hasil belajar peserta didik dalam pembelajaran IPS setelah tindakan siklus menggunakan model pembelajaran CLIS menunjukkan adanya peningkatan dari satu siklus perbaikan pembelajaran ke siklus berikutnya. Hasil belajar mata pelajaran IPS peserta didik kelas VIII-2 SMP Negeri 1 Buay Pemuka Peliung pada materi pembelajaran Permintaan dan Penawaran setelah tindakan siklus 1 masih tergolong rendah. Data menunjukkan terdapat 20 peserta didik atau $58,82 \%$ memperoleh nilai kategori rendah, 8 peserta didik atau $23,53 \%$ memperoleh nilai kategori sedang, dan 6 peserta didik atau $17,65 \%$ memperoleh nilai kategori tinggi. Selain kriteria sebagaimana tersebut, dilihat dari ketuntasan belajar diketahui bahwa dari 34 peserta didik terdapat 10 peserta didik atau $29,41 \%$ dapat mencapai ketuntasan dengan memperoleh nilai $>70$, sedangkan 24 peserta didik atau $70,59 \%$ belum dapat mencapai ketuntasan. Persentase tingkat ketuntasan belajar menunjukkan bahwa hasil belajar mata pelajaran IPS peserta didik setelah tindakan siklus 1 masih masuk dalam kategori rendah. Hal tersebut karena ketuntasan belajar sebesar 29,41\% berada pada interval $26-50 \%$ yang berarti ketuntasan belajar peserta didik adalah rendah.

Hasil belajar mata pelajaran IPS peserta didik pada siklus 2 adalah sedang. Data menunjukkan terdapat 18 peserta didik atau 52,94\% memperoleh nilai kategori sedang dengan nilai rata-rata 70,00 . Selain itu, dilihat dari tingkat ketuntasan belajar peserta didik hasil belajar mata pelajaran IPS melalui model pembelajaran CLIS menunjukkan adanya peningkatan dari siklus 1 . Pada siklus 1 jumlah peserta didik yang mencapai ketuntasan belajar dengan memperoleh nilai 70 berjumlah 10 peserta didik atau $29,41 \%$ menjadi 18 peserta didik atau 52,94\% pada siklus 2 . Peningkatan hasil belajar mata pelajaran IPS peserta didik dari siklus 1 ke siklus 2 sebesar $23,53 \%$.

Hasil belajar mata pelajaran IPS peserta didik setelah tindakan siklus 3 adalah baik. Data menunjukkan terdapat 16 peserta didik atau 47,06\% memperoleh nilai kategori baik dengan nilai rata-rata 80,00 . Hasil belajar peserta didik dalam pembelajaran IPS menunjukkan adanya peningkatan dari satu siklus perbaikan pembelajaran ke siklus berikutnya. Pada siklus 3 , peserta didik yang telah mencapai KKM atau mendapatkan nilai 70 berjumlah 32 peserta didik atau 94,12\%. Peningkatan hasil belajar peserta didik kelas VIII-2 SMP Negeri 1 Buay Pemuka Peliung dari siklus 2 ke siklus 3 mencapai $41,18 \%$. Dengan demikian ketuntasan 


\section{IMPLEMENTASI MODEL PEMBELAJARAN CHILDREN LEARNING IN SCIENCE (CLIS) UNTUK MENINGKATKAN HASIL BELAJAR IPS PESERTA DIDIK KELAS VIII DI SMP NEGERI 1 BUAY PEMUKA PELIUNG}

pelaksanaan pembelajaran IPS sudah mencapai $90 \%$ dari seluruh jumlah peserta didik.

- Peningkatan Hasil Belajar Peserta Didik Setiap Siklus

Tindakan perbaikan pembelajaran melalui model pembelajaran CLIS dalam pelajaran IPS mampu meningkatkan hasil belajar mata pelajaran IPS peserta didik kelas VIII-2 SMP Negeri 1 Buay Pemuka Peliung pada setiap siklusnya. Peningkatan aktivitas belajar IPS peserta didik kelas VIII-2 SMP Negeri 1 Buay Pemuka Peliung diikuti dengan hasil belajar peserta didik. Peningkatan hasil belajar mata pelajaran IPS materi pembelajaran Permintaan dan Penawaran peserta didik kelas VIII-2 SMP Negeri 1 Buay Pemuka Peliung melalui penerapan model pembelajaran CLIS setiap siklusnya sebesar $25,49 \%$. Hasil analisis tersebut kemudian dijadikan sebagai dasar kesimpulan akhir penelitian yaitu model pembelajaran CLIS dapat meningkatkan hasil belajar mata pelajaran IPS peserta didik kelas VIII-2 SMP Negeri 1 Buay Pemuka Peliung setiap siklusnya sebesar $25,49 \%$.

\section{Pembahasan \\ Hasil penelitian menunjukkan bahwa model pembelajaran CLIS efektif untuk diterapkan pada pembelajaran IPS materi pembelajaran Permintaan dan Penawaran. Penerapan model pembelajaran CLIS menjadikan peserta didik lebih mandiri dalam belajar, lebih aktif dalam memahami materi pembelajaran, dan memiliki pemahaman yang baik terhadap materi pembelajaran sehingga dapat memperoleh hasil belajar yang maksimal. Keadaan tersebut memperkuat pendapat Syafrina (2011:53) yang menyebutkan kelebihan model pembelajaran CLIS yaitu: \\ 1. Membiasakan peserta didik untuk belajar secara mandiri dalam mengatasi permasalahan. \\ 2. Dapat memberikan kemudahan kepada peserta didik dalam mempelajari materi pembelajaran. \\ 3. Terjalinnya kerjasama kelompok. \\ 4. Melatih peserta didik berpikir kritis dan kreatif. \\ 5. Mendorong peserta didik untuk berperan aktif dalam pembelajaran.}

Selama kegiatan penelitian tindakan, diketahui bahwa kelebihan model pembelajaran CLIS terletak pada kemandirian belajar peserta didik. Pembelajaran menggunakan model pembelajaran CLIS mendorong peserta didik untuk dapat terlibat aktif selama kegiatan pembelajaran melalui kegiatan kelompok. Kelebihan dari model pembelajaran CLIS adalah dapat menciptakan kreativitas peserta didik untuk belajar sehingga tercipta suasana kelas yang lebih nyaman dan kreatif, terjalinnya kerja sama sesama peserta didik dan peserta didik terlibat secara langsung dalam melakukan kegiatan dan menciptakan belajar lebih bermakna, karena timbulnya kebanggaan siwa menentukan sendiri konsep ilmiah yang sedang dipelajari dan peserta didik akan bangga dengan hasil temuanya. Selain itu, 
penerapan model pembelajaran CLIS dapat menjadikan pendidik dalam mengajar akan lebih mudah, karena dapat menciptakan suasana belajar yang lebih aktif, sehingga pendidik hanya menyediakan berbagai masalah yang berhubungan dengan konsep yang diajarkannya, sedangkan peserta didik bisa mencari sendiri jawabannya. Pendidik dapat menciptakan alat-alat atau media pembelajaran yang sederhana yang dapat ditemukan dalam kehidupan sehari-hari.

Keterbatasan penelitian tidak memaparkan keterbatasan waktu dan logistik yang dihadapi saat melakukan penelitian. Kesulitan-kesulitan yang mungkin dihadapi peneliti saat melakukan penelitian sudah harus diperhitungkan sebelum merencanakan penelitian. Keterbatasan penelitian memaparkan hal-hal atau variabel yang sebenarnya tercakup di dalam keluasan lingkup penelitian tapi karena kesulitankesulitan metodologis atau prosedural tertentu sehingga tidak dapat dicakup di dalam penelitian dan di luar kendalikan peneliti. Penelitian dapat dilaksanakan sesuai jadwal serta dapat memenuhi target yang telah ditetapkan. Meskipun demikian, pelaksanaan tindakan tidak luput dari berbagai kendala sebagai bentuk keterbatasan penelitian. Keterbatasan-keterbatasan penelitian dapat diuraikan sebagai berikut:

1. Waktu yang tersedia untuk penelitian ini relatif pendek sehingga ketuntasan belajar peserta didik tidak mencapai $100 \%$. Pada akhir kegiatan pembelajaran masih terdapat 2 peserta didik atau $5,88 \%$ belum dapat mencapai ketuntasan.

2. Penelitian tindakan hanya dilakukan pada satu materi pembelajaran yaitu Permintaan dan Penawaran sehingga masih membutuhkan berbagai penelitian lanjutan dengan cara menerapkan model pembelajaran CLIS pada materi pembelajaran IPS lain agar hasil penelitian ini benar-benar dapat terpercaya.

Hasil analisis keterbatasan penelitian hendaknya dapat dijadikan acuan untuk melaksanakan penelitian-penelitian selanjutnya. Meskipun demikian dapat diambil kesimpulan akhir bahwa penerapan model pembelajaran CLIS efektif diterapkan pada mata pelajaran IPS materi pembelajaran Permintaan dan Penawaran di kelas VIII SMP Negeri 1 Buay Pemuka Peliung. Penerapan model pembelajaran CLIS dapat meningkatkan ketuntasan hasil belajar peserta didik setiap siklusnya sebesar $25,49 \%$.

\section{SIMPULAN}

Berdasarkan analisis data dan pembahasan hasil penelitian dapat disimpulkan sebagai berikut:

1. Hasil belajar mata pelajaran IPS peserta didik sebelum tindakan menggunakan model pembelajaran Children Learning In Science (CLIS) di kelas VIII SMP Negeri 1 Buay Pemuka Peliung adalah rendah yaitu dari 34 peserta didik hanya terdapat 


\section{IMPLEMENTASI MODEL PEMBELAJARAN CHILDREN LEARNING IN SCIENCE (CLIS) UNTUK MENINGKATKAN HASIL BELAJAR IPS PESERTA DIDIK KELAS VIII DI SMP NEGERI 1 BUAY PEMUKA PELIUNG}

6 peserta didik atau $17,65 \%$ yang tuntas sedangkan 28 peserta didik atau $82,35 \%$ tidak dapat mencapai ketuntasan dengan nilai rata-rata sebesar 40,00.

2. Hasil belajar mata pelajaran IPS peserta didik setelah tindakan menggunakan model pembelajaran Children Learning In Science (CLIS) di kelas VIII SMP Negeri 1 Buay Pemuka Peliung adalah tinggi atau baik yaitu pada akhir siklus 3 dari 34 peserta didik terdapat 32 peserta didik atau $94,12 \%$ dapat mencapai ketuntasan dan hanya 2 peserta didik atau $5,88 \%$ tidak apat mencapai ketuntasan dengan nilai rata-rata sebesar 80,00 .

3. Implementasi model pembelajaran Children Learning In Science (CLIS) dapat meningkatkan hasil belajar IPS peserta didik kelas VIII SMP Negeri 1 Buay Pemuka Peliung yaitu setelah tindakan siklus 1 terjadi peningkatan hasil belajar sebesar $11,76 \%$ dari tindakan prasiklus. Pada siklus 2 terjadi peningkatan sebesar $23,53 \%$. Pada siklus 3 terjadi peningkatan sebesar $11,78 \%$. Implementasi model pembelajaran Children Learning in Science (CLIS) dapat meningkatkan hasil belajar peserta didik rata-rata $25,49 \%$ pada setiap siklusnya.

\section{UCAPAN TERIMAKASIH}

Ucapan terimakasih ditujukan kepada STKIP Nurul Huda Sukaraja yang menjadi bagian perjalanan menempuh pendidikan Sarjana Pendidikan Ekonomi dan juga kepada seluruh pihak yang telah ikut serta dalam pembuatan skripsi penulis. Kepada kedua orang tua dan kedua pembimbing penulis, serta teman-teman seperjuangan yang telah menorehkan banyak cerita dan juga pengalaman. Terimakasih juga kepada tim Journal UTILITY STKIP Nurul Huda.

\section{REFERENSI}

Asrori, M. (2011). Penelitian Tindakan Kelas. Bandung: CV. Wacana Prima.

Depdiknas. (2010). Undang-undang Nomor 20 Tahun 2003 Tentang Sistem Pendidikan Nasional. Jakarta: Depdiknas.

Hamdani, N.A. (2012). Classroom Action Research; Teknik Penulisan dan Contoh Proposal Penelitian Tindakan Kelas (PTK). Jakarta: Rahayasa.

Hariyati, R. (2015). Implementasi Model Pembelajaran Children Learning In Science (CLIS) Untuk Meningkatkan Hasil Belajar Ekonomi Peserta Didik Kelas X IPS 3 SMA 1 Bae Tahun Ajaran 2014/2015. Jurnal Skripsi. 


\section{Oktavia Pawari ${ }^{1}$, Vovi Sinta ${ }^{2}$, Miftakhur Rohmah ${ }^{3}$}

http://journals.ums.ac.id/index.php/varidika/article/view/5146. Posted: 16 Mei 2015. $10.37 \mathrm{pm}$.

IImi, M. (2012). Meningkatkan Hasil Belajar IPS Menggunakan Model Pembelajaran Children Learning In Science (CLIS) di Kelas VII MTs Miftahul Ulum Pondok Labu Jakarta Selatan. Jurnal Skripsi. http://etd.repository.ugm.ac.id/=html. Posted: 06/08/2012. 09.00 pm.

Muslich, M. (2010). Melaksanakan PTK Itu Mudah. Jakarta: Bumi Aksara.

Mustofa, A. (2011). Belajar dan Pembelajaran; Pengembangan Wacana dan Praktek Pembelajaran dalam Pembangunan Nasional. Yogyakarta: Arruz Media.

Sukardi. (2013). Metode Penelitian Kualitatif dan Kuantitatif Untuk Psikologi dan Pendidikan. Bandung: Remaja Rosdakarya.

Suyono. (2011). Belajar dan Pembelajaran; Teori dan Konsep Dasar. Bandung: Remaja Rosdakarya.

Syafrina, D. (2013). Model Pembelajaran Berbasis Fenomena dengan Pendekatan Inkuiri Terbimbing untuk Meningkatkan Pemahaman Konsep Pembiasan Cahaya dan Keterampilan Generik Sains Peserta Didik SMP. Diakses dari http://repository.upi.edu/8902/pada tanggal 18 Desember 2016 pukul 12.00 WIB. 